\title{
"Factors Responsible For the Incidence of Child Labour: A Study in Cuttack City, Odisha"
}

\author{
Mr. Prasant Kumar Behera ${ }^{1}$, Subhasmita Das ${ }^{2}$ \\ ${ }^{1}$ Assistant Professor of Economics, Central University of Orissa, Koraput \\ ${ }^{2}$ Lecturer in Mathematics, Central University of Orissa, Koraput
}

\begin{abstract}
The prevalence of child labour is one of the most important socio-economic problems confronting the society. As estimated in the census figure, poverty and the incidence of child labour are very high in the state of Odisha. Therefore, to focus on the nature and magnitude of the problem and for finding out the main reason of their participation in the workforce at an early age, a micro level study has been made in Cuttack City. The objective of the study is to identity the factors responsible for the incidence of child labour in Cuttack city. In view of the objective, the study relied mostly on primary data. The relevant information is elicited from 100 child labourers of Cuttack City, Odisha with the help of a structured questionnaire. Besides getting information through the primary source, secondary data has also been collected from Labour \& Employment Department of Odisha, NCLP Society, NSSO, Census of India, ILO, and UNICEF. The economic conditions of the child labourers are analysed in terms of their employment status including hours of working, wage rate, family income, child labour's contribution towards family income etc. through simple tables and figures. The hypothesis, i.e. the determinants of incidence of child labour has been identified and estimated with the help of a multiple regression model. Regarding factors responsible for the incidence of child labour, it has been found that poverty or low income is the major factor. 52 percent child labour indicated that poverty is the main cause of their work. There are also other reasons such as death of parents, big size of family, child's desire to work, etc. The study suggests that children's development and the overall eradication of child labour problem of Cuttack depend on active public private partnership, proper government policies and programmes for eliminating poverty and unemployment, free basic facilities, awareness among the people, active participation of the citizens and local bodies, education to extreme poor and particularly women's education.
\end{abstract}

\section{Introduction}

The prevalence of child labour is one of the most important socio-economic problems confronting the world at large, especially developing countries such as India. In many cases, child labour is mainly necessitated by economic compulsions of the parents. Many appalling realities like poverty, illiteracy, unemployment, low wages, ignorance, social prejudices, regressive traditions, poor standard of living, backwardness, superstition, low status of women have combined to give birth to the terrible practice of child labour. The main reason which gives rise to child labour is widespread unemployment and underemployment among the adult poor strata of the population due to sharp growth of population. Large families with low income and often lack of educational facilities, illiteracy and ignorance of parents about the importance of education as well as about the impact of labour on the health of their children are some of the reasons which breed child labour. According to UNICEF, State of the World's Children 2010, an estimated 12 percent of children in India ages 5-14 are engaged in child labour activities. The practice deprives children of their childhood, and is harmful to their physical and mental development. The problem is widespread and not confined to any particular economy. It is prevalent in both rural and urban areas. Moreover, following the rapid industrialization and urbanization, child labour in cities has greatly increased due to migration of people from rural to urban areas.

\section{Child Labour In India}

The problem of child labour exploitation is a major challenge to the progress of developing countries. This is particularly serious in India as it tops the list with the highest number of child labourers in the world. Child labour in India is the practice where children engage in economic activity, on part-time or full-time basis. Poverty, lack of good schools and growth of informal economy are considered as the most important causes of child labour in India. The 2001 Census of India estimated the total number of child labourers, aged 5-14, to be at 12.6 million. UNICEF estimates that India with its larger population has the highest number of labourers in the world under 14 years of age. International Labour Organization estimates that agriculture, at 60 percent, is the largest employer of child labour in India. Outside of agriculture, child labour is observed in almost all informal sectors of the Indian economy. According to NSSO, 2009-10 survey, the total child labour in India between age group 5-14 was 49,83,871, where percentage of males is 61.36 and percentage of females is 38.64 . The highest numbers of child labourers are in Uttarakhand i.e. 17,75,333, constituting 35.62 percent of the total 
percentage of child labour in India. Kerala has the lowest number of child labour i.e. 2765 and 0.06 percent of the total. In Odisha the total number of child labourers are 13,45,63, constituting 2.70 percent of the total, where 67.56 percent are males and 32.44 percent are females.

\section{Child Labour In Odisha}

The absolute number of child labourers according to Census 1991 was 4,52,394, which constituted 4.01 percent of total child labour in the country, the absolute number of child labour in Odisha declined to 2,15,222 in 1997 and it further decreased to 3,77,594 in 2001 census. In 2006, the absolute number of child labour in the state increased to 4.86,461 and in 2009-10, it decreased to 1,34,563 and finally in 2011 it increased to 1,69,995. According to the survey report of the Directorate of Labour and Employment, Government of Odisha, 90 percent of child labour in Odisha comes from the rural areas. In cities and towns, growth of urban slums propels the child labour force. The statistics available on child labour shows only a trend, but this in no way reflects the constituting proportion of children in workforce. No official facts are available on the children working day \& night outside of their family homes and toiling as domestic child labourers. They are all exploited, exposed to hazardous work and grossly abused because working arrangement is informal and social protection is almost non-existent.

\section{Child Labour In Cuttack}

As the old capital and most populated city of Odisha, a major railway hub of the east coast, Cuttack attracts countless numbers of homeless and poverty-stricken families migrating from rural areas in search of work. According to a survey by NCLP Society, Cuttack, approximately 42 percent of the total city population is living in slums in unimaginable conditions where crime and alcohol is mare rampant. Of these slums in habitants, some 30,000 are children who have found ways to survive on the streets, railways and rubbish heaps by rag-picking, begging, scavenging, and vending. Generally the people are living in these places are Telugu, Bengali and Muslim migrants from Andhra Pradesh, West Bengal and other areas who have scattered to Mal go down, Badambadi, Buxi Bazar, Railway station, Tulsipur, Naya Bazar and several other places in the city of Cuttack. According to the 2011 Child Labour Survey by the State Labour Institute, Bhubaneswar, the total number of child labourers in Cuttack district was 3,472 or 2.04 percent of the total child labourers in all NCLP districts of Odisha, out of which 49.25 percent are males and 50.75 percent are females. So the number of female child labourers is more than the male child labourers. A total of 2,006 child labourers are found in nonhazardous sector from which 890 are males and 1,116 are females. Similarly in hazardous sector, there were total 1,466 child labourers out of which 820 are males and 646 are females. Total number of child labourers in age group 6-8 was 632 and it is more in the age group 9-14 which stands at 2,840.

Despite various legislative measures undertaken by the government, the problem is rampant in certain sectors of the economy and the abuse of children is found in an alarming proportion. As estimated in the census figure, the poverty and the incidence of child labour are very high in this state of Odisha. Therefore, to focus on the nature and magnitude of the problem and for finding out the main reason of their participation in the workforce at an early age, a micro level study, in Cuttack City has been made.

\section{Objective Of The Study}

To identity the factors responsible for the incidence of child labour in Cuttack city.

\section{Hypothesis}

The study seeks to examine the following hypothesis.

- That the incidence of child labour is not only determined by the poor economic condition of the household but also by a set of factors like family size, education of the child and education of the parents.

\section{Data Sources And Sampling Design}

In view of the objective the study relied mostly on primary data. The relevant information was elicited from 100 child labourers of Cuttack City, Odisha with the help of a structured questionnaire. The study was based on two-stage sampling. Since reliable frame is available on child labour in Cuttack city, this type of sampling was taken. In the first stage on the basis of high availability of child labourers, five places namely Badambadi, Pattapol, Tulasipur, Buxi Bazar and Railway Station were selected and in the second stage randomly samples were taken from these selected areas. Besides getting information through the primary source, secondary data was also collected from Labour \& Employment Department of Odisha, NCLP Society, NSSO, Census of India, ILO, and UNICEF. 


\section{Methodology}

The economic conditions of the child labour are analysed in terms of their employment status including hours of working, wage rate, family income, child labour's contribution towards family income etc. through simple tables and figures. The hypothesis, i.e. the determinants of incidence of child labour has been identified and estimated with the help of a multiple regression model.

\section{Review Of Literature}

To get a better insight into the problem of factors influencing the incidence of child labour, a brief review of the available studies on child labour are conducted to analyse the different reasons of child labour. Researchers described large concentration of child labour in India as well as in the world to various factors.

According to Mustafa, M. and Onkar, S. (1990) apart from acute poverty, child labour, by and large, is a product of unemployment and underemployment of the adult wage earner. This is also the reason for increasing demand for child labour. Naidu, M. C. (1985) considered poverty and inequity in income to be the major causes of child labour. Burra, N. (1989) considered poverty as one of the main reasons of child employment. According to her, another major cause is that the employer had a vested interest in the continuation of child labour as it is profitable. Nangia, P. (1991) from her survey in the metropolitan city (Delhi) concluded that apart from poverty, the low educational and occupational status of the parents and inadequacy of the legislative system as well as its insufficient enforcement, are the other reason for the persisting incidence of child labour. Kanbargi, R. (1991) considered poverty and illiteracy to be the two major factors associated with child labour. Apart from these he found that the level of father's education and aspiration are closely associated with child labour. Like many others, Tripathy, S. K. (1989) also stated that poverty and illiteracy are the two major factors that drove these small children to the labour market in spite of many legislations existing for their protection and for prohibition of their employment. He further observed that larger numbers of female child labour are engaged in domestic activities of people residing in urban centres. Subramanian, M. S. (1990) observed that the main reason of employing child labour is the relatively cheaper wage rate than that of the adult worker which ensured them to derive more margin of profit over less investment.

In a micro level study of child labour in Bhubaneswar city, Pati, R. N. (1991) indicated that disorganized family structures and dilapidated rural economy coupled with other socio-economic factors forced a large chunk of rural children to migrate to urban areas for jobs. In a study of the problem of child labour in the tribal districts of Odisha, Tripathy, S. N. (1991) pointed out that the backwardness of agriculture, the increasing dependence of the people in agriculture, complete neglect of industrialization, excessive land revenue, and exploitation of poor peasants by the Zamindars and Money lenders, reduced the people of Odisha to extreme poverty. The rural indebtedness, failure of crops, illiteracy, callous attitude of Government, ineffective implementation of the policy plans, etc. contributed to the growth of child labour. Dixit, A. (1997) observed that the causes of girls child labour are unemployment among the parents, poverty, inadequate distribution of land and assets, inadequate income of adults, migration of labour, social and cultural factors, educational backwardness, ignorance of parents, bonded labour system and large families etc. Rena, R. (2008) found that hundreds of children, due to the poverty, are forced to work as labourers before they even enter school and many must leave school in the middle of a course of study to become labourers. Once children are snatched from school and put to work, they are cut off from their normal development, education and relationships.

\section{Socio-Economic Condition Of Child Labour In Cuttack City}

Various socio-economic characteristics of child labour in terms of their age, sex, educational status, employment status including hours of working, wage rate, family income, child labour's contribution towards family income etc through simple tables and figures have been discussed below.

\section{Basic Causes and Sex of Child Labour}

Poverty is a social curse which makes a section of the society deprived of the basic necessities of life. The study considers Rs. 18,000 per households per annum as the indicator of poverty. It is generally believed that poverty is the main cause of child labour. There are also other reasons such as death of parents, big size of family, child's desire to work etc. This becomes evident from an analysis of the data presented in Table 1.

Table-1 Distribution of Working Children Based on the Basic Causes and Sex

\begin{tabular}{|l|l|l|l|l|}
\hline Sl. No. & Reasons & \% of Boys & \% of Girls & Total \\
\hline 1 & Poor Economic Condition & 30 & 22 & 52 \\
\hline 2 & Death of Earning Member/ Orphanage & 4 & 2 & 6 \\
\hline 3 & Big Size of Family & 14 & 8 & 22 \\
\hline 5 & Child's Desire to Work & 12 & 4 & 16 \\
\hline 6 & Other Reason & 2 & 2 & 4 \\
\hline 7 & Total & 62 & 38 & 100 \\
\hline
\end{tabular}

Source: Own Survey 
It is seen from the above table that out of total respondents, 52 percent indicated that poverty is the main cause of their work, 6 percent said they are in the workforce because of the death of their main earning member/orphanage, 22 percent said that they work due to big size of the family. Overall, child's desire to work is $16 \%$ and amongst other reasons, the most important ones are illiteracy and ignorance of the parents. From the survey, it is found that 62 percent of child labourers are males and rest 38 percent are females.

\section{Educational Status of Child Labour}

The distribution of child labour according to their educational status namely illiterate, primary and secondary have been explained in the following table.

Table-2 Distribution of Child Labour Based on the Education

\begin{tabular}{|l|l|l|l|}
\hline Education & Boys \% & Girls \% & Total \% \\
\hline Illiterate & 40 & 30 & 70 \\
\hline Primary & 14 & 6 & 20 \\
\hline Secondary & 8 & 2 & 10 \\
\hline Total & 62 & 38 & 100 \\
\hline
\end{tabular}

Source: Own Survey

It can be seen from the above table that 70 percent child labourers have never been to school. A higher proportion of boys 40 percent and 30 percent of girls are illiterate. Only 8 percent of boys and 2 percent of girls have education up to secondary school. After that they quit either due to poverty or due to death of the earning members mostly. The percentage of primary school attendance among the boys is 14 and among the girls is 6 percent of the total working children; they dropout before fifth year of schooling. It can be understood from the table that both male and female children have not been afforded educational opportunities which compel them to go for work at early age. The main reason behind the dropout from school is poverty and illiteracy of their parents.

\section{Annual Income of the Parents of Child Labour}

The annual income of the parents of the child labourers has been categorised in three groups say up to Rs 18,000, Rs 18,001-25,000 and above Rs 25,000. The distribution has been expressed in the following table-3.

Table-3 Distribution of Child Labour Based on the Annual Income of the Parents

\begin{tabular}{|l|l|}
\hline Income Group (in Rupees) & Percentage \\
\hline Up to 18,000 & 52 \\
\hline $18,001-25,000$ & 32 \\
\hline Above 25,000 & 16 \\
\hline Total & 100 \\
\hline
\end{tabular}

Source: Own Survey

As shown in the above table, 52 percent parents have annual income up to Rs. 18,000 rupees. Only 16 per cent parents have annual income above Rs. 25,000 and 32 percent have income between Rs. 18,001- 25,000 per annum. So, it is quite obvious that they send their children to work to supplement the family's income. Due to low income of the family, children are deprived of the educational and other facilities which are essential for the proper growth and development.

\section{Education and Annual Income of the Family}

Annual income of a family plays a significant role in the education of their children. Children having good family income support get enough scope for education, where as the children from poor family income group are deprived of, or get less encouragement for, education. It is presented in the following table.

Table-4 Distribution of Child Labour Based on their Education and Annual Income of the Family

\begin{tabular}{|l|l|l|l|l|}
\hline Educational Level & \multicolumn{2}{|l|}{ Annual Income (In Rs.) } & Total \\
\hline & Up to 18,000 & $18,001-25,000$ & Above 25,000 & \\
\hline Illiterate & $42 \%$ & $18 \%$ & $10 \%$ & $70 \%$ \\
\hline Primary & $10 \%$ & $6 \%$ & $4 \%$ & $20 \%$ \\
\hline Secondary & & $8 \%$ & $2 \%$ & $10 \%$ \\
\hline Total & $52 \%$ & $32 \%$ & $16 \%$ & $100 \%$ \\
\hline
\end{tabular}

Source: own survey 
It is evident from the above table that up to income Rs.18,000, there are 42 percent illiterate and only 10 percent have education up to primary and no one has touched the secondary level. Between income level Rs. 18,001- Rs25,000, around 18 percent are illiterate, 6 percent have completed primary level and only 8 percent have secondary education. And income group above Rs. 25,000 witnesses 10 percent illiterates, 4 percent of primary level and 2 percent child labour of secondary education level. Regarding the annual income of the parents of child labourers, it is observed that due to low income, children are sent to work places as labourers and they miss the opportunity of education.

\section{Occupational Distribution}

The occupational distribution of the child labourers on the basis of various economic activities is being presented in the following figure-1.

Fig-1 Distribution of Child Labour According to Occupational Category

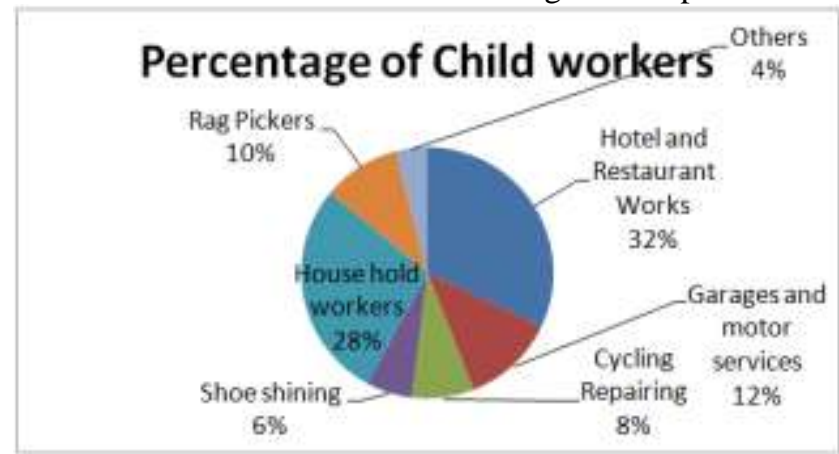

Source: Own Survey

According to the Survey, around 32 percent are found working in hotels and restaurants. The second highest, which accounts to 28 percent, child labourers are found in household works in which maximum are girl child workers. In garages, shoe shining shops and cycle repairing shops, maximum boy child workers are found. In other category, hawkers, vendors, decorative gas light carriers in function etc. are included. However, the occupational structure of child workers does not remain the same, sometimes they perform a single specialized work and it keeps on changing.

\section{Average Annual Income of the Household}

Child labour income plays a significant role in the family income. Some poor families even rely fully on their child labour income for their survival. The effect of contribution of child labour income (in terms of rupees) in the average annual income of the household is presented in the following table.

Table-5 Average Annual Income of Household Before and After the Contribution of Child Labour

\begin{tabular}{|l|l|}
\hline Category & Average Annual Income (in Rupees) \\
\hline Before contribution of child labourers & 15,419 \\
\hline Contribution of child labourers & 4,490 \\
\hline After contribution of child labourers & 19,909 \\
\hline
\end{tabular}

Source: Own Survey

It is evident from the above table that the percentage average income of the households without the contribution of child labour is only 15,419 rupees. Taking the contribution of child labourers into consideration, the average income of the household is raised to Rs. 19,909; and the contribution of child labour to average income constitutes Rs. 4,490. Nearly one-fourth of the household income is contributed by child labour. The contribution of child labourers clearly indicates a positive impact on the annual income of the households.

\section{Annual Income of the Child Labour}

The annual income of the child labour is presented in the following table.

Table-6 Annual Income of the Child Labour

\begin{tabular}{|l|l|}
\hline Income Level (In Rs.) & Percentage \\
\hline Up to 4,000 & 14 \\
\hline $4,001-7,000$ & 58 \\
\hline $7,001-10,000$ & 28 \\
\hline Total & 100 \\
\hline
\end{tabular}

Source: Own Survey 
The above table shows that 58 percent of the child labourers earn an annual income of Rs. 4,001 to Rs. 7,000, 28 percent child labourers earn Rs. 7,001 to Rs. 10,000 annually and rest 14 percent earn income only up to Rs. 4,000 per year. So it is observed that the income level of the child labourers is very low and it is not sufficient even for the basic standard of living. They are under paid and, in some cases, they work only with two meals and no cash payment.

\section{Hours of Work}

Child labourers do not enjoy fixed working hours. It varies from one occupation to another. Therefore, a great variation is found in the hours of work of the economically active children, which spread over from four hours to 12 hours a day. Generally they go for work in the morning time up to lunch hours or from the afternoon to the evening according to the need of their work. Some child labourers like those who work in the hotels \& restaurants of Buxi Bazar and other areas work from 6AM to 6 PM daily and sometimes up to 9PM in the night.

Table-7 Distribution of Child Labour Based on the Daily Hours of Work

\begin{tabular}{|l|l|}
\hline Working Hours & Percentage \\
\hline Up to 4 & 18 \\
\hline 5 to 8 & 28 \\
\hline $9-12$ & 54 \\
\hline Total & 100 \\
\hline
\end{tabular}

Source: Own Survey

The above table shows that most of the child workers, about 54 percent, work for 9 to 12 hours a day. Sometimes they are found working from the early hours of morning till evening where as only 28 percent work for 5 to 8 hours a day and 18 percent work for 4 hours a day. As far as weekly offs are concerned, only some of the children working in garages and cycle repairing shops get the facilities. As a matter of fact, the selfemployed children avail this facility as well. They are mostly governed by the rule 'no work no pay'.

\section{Other Occupational Information}

Mostly they work as temporary or casual workers, as they keep on changing from one job to another. Some jobs are contractual like household work. There occurs an agreement between the employer and child workers or between the employer and parents of the child labourers. Some workers are seasonal in nature like vendors. The earning of these child labourers is very less even for their own livelihood. Maximum of them get Rs 40 to 60 per day. Very few get more than Rs. 60. On holidays they remain at home on the basis of 'no work no pay'. Around 75 percent of these child labourers are not satisfied with their job. They are exploited by their employers and sometimes it leads to physical assault. Usually, festival season like Dusshera, Baliyatra, etc are the peak season of income for them as their employers get better business and profit. Otherwise, they work with less payment and they hardly get any alternative in dry season of their work. Child are not enough grown up for strong physical work. So any heavy work or work beyond their capacity makes them ill. Working for long hours and restless heavy work have a bad impact on the child labourers. Due to this they suffer from many diseases. Most of the children say 72 percent are suffering from back pain, body pain and cold. About 10 percent children are suffering from asthma and 8 percent children are suffering from chest pain. Very few of them have taken free preventive injections in their childhood. Usually they don't go for any medical check up even not once in a year. But they fall sick often and even in sickness they go for work.

\section{Determinants Of Child Labour}

There have been legislations to prevent child labour and protect children when they are employed, but still the incidence of child labour is very high in Cuttack city. There are several factors which are responsible for the early entry of children in the labour force. These are mostly poverty, size of the family, illiteracy, orphanage, wage rates, etc as observed from empirical study. All these factors are interlinked, and children become workers because of many reasons and form a part of the labour force. This section focuses on the determinants of child labour in Cuttack city.

\section{Regression Analysis}

In this section, a multiple regression model is used in order to know the relative significance of the factors determining the child work participation. The incidence of child labour is determined by various factors, i.e., poverty or low family income, family size, education of parents, etc. as discussed in the preceding section. In order to identify the significant determinants of child labour, a regression model has been fitted by taking into consideration the most possible determinants of child labour. For the purpose of regression, five variables have been taken into consideration. The independent variables used in the regression model are family income, family 
size, education of child labour, education of father and education of the mother of child labour. The dependent variable is the working hour of child labour.

The model is as follows.

$Y=\alpha+\beta_{1} X_{1}+\beta_{2} X_{2}+\beta_{3} X_{3}+\beta_{4} X_{4}+\beta_{5} X_{5}+U$

Where $\mathrm{Y}=$ Working hour of child labour

$\mathrm{X}_{1}=$ Family income (annual income in rupees)

$\mathrm{X}_{2}=$ Family size (in number)

$\mathrm{X}_{3}=$ Education of child labour (in terms of schooling years)

$\mathrm{X}_{4}=$ Education of father of child labour (in terms of schooling years)

$\mathrm{X}_{5}=$ Education of mother of child labour (in terms of schooling years)

$\alpha=$ Intercept term

$\beta_{1}, \beta_{2}, \beta_{3}, \beta_{4}$, and $\beta_{5}$ are co-efficeints of $X_{1}, X_{2}, X_{3}, X_{4}$ and $X_{5}$ respectively.

$\mathrm{U}=$ Error term

Table-8 Regression Results of Incidence of Child Labour

(Dependent Variable, $\mathrm{Y}=$ working hour of child labour), $\mathrm{N}=100$

\begin{tabular}{|c|c|c|c|c|c|c|c|c|c|}
\hline \multicolumn{10}{|c|}{ Coefficients of Independent Variables } \\
\hline Sl. No. & $\begin{array}{l}\text { Constant/ } \\
\text { Intercept }\end{array}$ & $\begin{array}{l}\text { Family } \\
\text { Income } \\
(\mathrm{X} 1)\end{array}$ & $\begin{array}{l}\text { Family } \\
\text { Size } \\
(\mathrm{X} 2)\end{array}$ & $\begin{array}{l}\text { Education of } \\
\text { the children } \\
\text { (X3) }\end{array}$ & $\begin{array}{l}\text { Education } \\
\text { of father } \\
\text { (X4) }\end{array}$ & $\begin{array}{l}\text { Education } \\
\text { of mother } \\
\text { (X5) }\end{array}$ & $\mathrm{R}^{2}$ & $\overline{\mathrm{R}}^{2}$ & F- Value \\
\hline 1 & $\begin{array}{l}3.547 \\
(2.636)\end{array}$ & $\begin{array}{l}-0.458 \text { *** } \\
(4.567)\end{array}$ & & & & & 0.514 & 0.503 & 86.722 \\
\hline 2 & $\begin{array}{l}1.229 \\
(2.937)\end{array}$ & $\begin{array}{l}-0.345 \text { **** } \\
(3.984)\end{array}$ & $\begin{array}{l}0.580 * * \\
(1.985)\end{array}$ & & & & 0.535 & 0.512 & 62.274 \\
\hline 3 & $\begin{array}{l}3.007 \\
(2.106)\end{array}$ & $\begin{array}{l}-0.283 \text { *** } \\
(2.587)\end{array}$ & $\begin{array}{l}0.286 * * \\
(1.995)\end{array}$ & $\begin{array}{l}-0.453 * * \\
(2.527)\end{array}$ & & & 0.546 & 0.521 & 54.213 \\
\hline 4 & $\begin{array}{l}2.887 \\
(2.064) \\
\end{array}$ & $\begin{array}{l}-0.316^{\text {**** }} \\
(4.836)\end{array}$ & $\begin{array}{l}0.236^{*} \\
(1.721) \\
\end{array}$ & $\begin{array}{l}-0.323 \\
(0.695) \\
\end{array}$ & $\begin{array}{l}-0.363^{* * * *} \\
(2.740)\end{array}$ & & 0.558 & 0.536 & 48.891 \\
\hline 5 & $\begin{array}{l}2.629 \\
(1.804)\end{array}$ & $\begin{array}{l}-0.318 \text { *** } \\
(2.835)\end{array}$ & $\begin{array}{l}0.290 * * \\
(2.473)\end{array}$ & $\begin{array}{l}-0.257 * * * \\
(2.194)\end{array}$ & $\begin{array}{l}-0.208^{*} \\
(1.672)\end{array}$ & $\begin{array}{l}-0.325 \\
(0.685)\end{array}$ & 0.569 & 0.541 & 39.497 \\
\hline
\end{tabular}

Source: Calculations from Primary Data

Figures in the parentheses indicate ' $t$ ' values.

*** Significant at 1 percent level, ** Significant at 5 percent level, * Significant at 10 percent level.

In this study, family income has been taken as the indicator for measuring poverty or poor economic condition of the family. Five equations have been taken to show the impact of all factors separately. The regression result is presented in Table- 8 .

\section{Regression Result}

In all the five models family income is the most dominant factor in determining the child labour. In the first model we can see that; one unit increase in family income, working hour of child labour decreases by 0.458 hour. In this model, the $\mathrm{R}^{2}$ value indicates i.e. around $51 \%$ variations in child labour is explained alone by family income. In all the models income remains negative and significant at $1 \%$ level of significance. Similarly family size also turned out to be an important factor in determining the child labour, but not as significant as the family income. In most of the models it is significant at $5 \%$ level of significance. Sign of its coefficient remains positive in all the regression. This indicates that; an increase in the size of family leads to an increase in the working hour of child labour. Education of child itself is a deterministic factor of child labour. In model-3 we can see that for one unit increase in education of child labour, working hour decreases by 0.453 hour. In model4 we have controlled for the father's education. One unit increase in father's education decreases the working hour of child labour by 0.363 hour. And in this model we can see that controlling for father's education is slightly decreasing the effect of family income ( -0.458 in model- 1 to -0.316 in model- 4$)$ and family size $(0.580$ in model-2 to 0.236 in model-4) on incidence of child labour. Sill the family income remains highly significant factor in determining incidence of child labour .In model-5, we can see that mother's education is hardly affecting the incidence of child labour. It is insignificant in this equation. However both child's education and father educations remain significant. Family income (-0.318) is also highly significant in this model. Also we can see from $\mathrm{R}^{2}$ value of this model that 56.9 percent variation in $\mathrm{Y}$ has been explained by the regressors (family income, family size, child's education, father's education and mother's education).From the table we can say that income of the family is the sole cause of child labour. Even if we control for the family size, education of the parents and education of the child, a decrease in income will lead to an increase in child labour. Moreover, it is estimated that family income (X1), family size (X2), child's education (X3), father's education (X4) and 
mother's education (X5) explain 51.4 percent $\left(\mathrm{R}^{2}=0.514\right), 27.7$ per cent $\left(\mathrm{R}^{2}=0.277\right)$, 6.1 per cent $\left(\mathrm{R}^{2}=\right.$ $0.061), 9.1$ percent $\left(R^{2}=0.091\right), 5.7$ percent $\left(R^{2}=0.057\right)$ variation in the dependent variable i.e., working hour of child labour (Y) respectively. This implies that family income is, statistically, the most important variable in influencing the working hour of child labour. Moreover, the ' $t$ ' values of the regression coefficients show that family income is statistically significant in all regression equation 1,2,3,4 and 5 and all the estimated ' $t$ ' values is greater than the tabulated ' $t$ ' values at 1 percent level of significance.

Hence, the null hypothesis - "That the incidence of child labour is not only determined by the poor economic condition of the household but also by a set of factors like family size, education of the child and education of the parents" is rejected. So we can clearly state that the child labour is only caused by the poor economic condition of the household/poverty and not by the other factors such as family size, education of the child and education of the parents.

\section{Main Findings}

1) Regarding the determinants of child labour, it has been found that poverty or low income is the major factor. 52 percent child labour indicated that poverty is the main cause of their work.

2) 76 percent child labourers are found in the age group 9-14 and rest 24 percent are in the age group 6-8.

3) 70 percent child labourers have never been to school. A higher proportion of boys 40 percent and 30 percent of girls are illiterate. Only 8 percent of boys and 2 percent of girls have education up to secondary school.

4) 52 per cent of the child labour parents have income up to Rs 18,000 . Only 16 percent parents have annual income above Rs. 25,000 and 32 percent have income between Rs. 18,001- Rs. 25, 000 per annum. So, it is quite obvious that, they send their children to work to supplement the family's income. Due to low income of the family, children are deprived of the educational and other facilities which are essential for the proper growth and development.

5) Regarding the nature of work of child labour, it is observed that 32 percent are found working in Hotel and Restaurants. The second highest, which stands at 28 percent, child labourers are found in household works in which maximum are girl child workers. In the activities of hotel \& restaurants, garage \& motor services, cycle repairing and shoe shining, mostly boys are engaged. Girls are mostly employed in household work. In other categories, hawkers, vendors, decorative gas light carriers in function etc. are included.

6) Child labourers do not enjoy fixed working hours. It varies from one occupation to another. Therefore, a great variation is found in the hours of work of the economically active children, which spread over from four hours to 12 hours a day. Generally they go for work in the morning time up to lunch hours or from the afternoon to the evening according to the need of their work. Some child labourers like those who work in the hotels \& restaurants of Buxi Bazar and other areas work from 6AM to 6 PM daily and sometimes up to 9PM in the night.

7) Survey shows that most of the child workers, as many as 54 percent, work for 9 to 12 hours a day. Sometimes they are found working from the early hours of morning till evening, where as only 28 percent work for 5 to 8 hours a day and 18 percent work for 4 hours a day. As far as weekly offs are concerned, only some of the children working in garages and cycle repairing shops and some self employed children get the facilities. They are mostly governed by the rule 'no work no pay'.

8) Mostly they work as temporary or casual workers, as they keep on changing from one job to another. Some jobs are contractual like household work. There occurs an agreement between the employer and child workers or between the employer and parents of the child labour. Some workers are seasonal in nature like vendors.

9) The earning of these child labourers is very less even for their own livelihood. Maximum of them get Rs 40 to Rs. 60 per day. Very few get more than Rs 60 . On holidays, they remain at home on the basis of 'no work no pay'. Around 75 percent of these child labourers are not satisfied with their jobs.

10) Child labour income plays a significant role in the family income. The contribution clearly indicates a positive impact on the annual income of the households of the child labourers.

11) It is found that about 58 percent of the child labourers earn an annual income of Rs 4,001 to Rs. 7,000. 28 percent child labourers earn Rs. 7,001 to Rs. 10,000 annually and rest 14 percent earn income only up to Rs. 4,000 per year. So it is observed that the income level of the child labourers is very low and it is not sufficient even for the basic standard of living. They are under paid and, in some cases, they work only with two meals and no cash payment. It is also found that an educated child earns more than an illiterate child labour.

12) In some cases, children are forced to work in hotels or pick wastes from the roadside. But nobody seems to care. Nobody takes a step forward. In the premises of railway stations and Badambadi bus stand, children are often seen by the police picking rags and working in the hotels but these policemen turn a blind eye to the entire situation. 
13) More than 20 percent of child labourers are forced to work at hazardous place. They also do over duties with no incentives. If they raise their voice, they are beaten and tortured by the employers. Girls do the same work as boys do but they are paid less.

14) 40 percent of child labourers have the view that they had worked 3-4 months without any wage after which their employer kicked them out without any reason, as there was no agreement between them.

15) 25 percent of the girl child labourers are working in restaurants and hotels, where they have been getting good meals but most of the girl children were physically abused over there.

16) Usually, festival season like Dusshera, Baliyatra, etc are the peak season of income for the child labourers as their employers get better business and profit. Otherwise, they work with less payment and they hardly get any alternative in dry season of their work.

17) Most of the children say 72 percent are suffering from back pain, body pain and cold. About 10 percent suffering from asthma and 8 percent child labourers suffering from chest pain. Usually they don't go for any medical check up even not once in a year. But they fall sick often and even in sickness they go for work.

\section{Suggestions And Conclusion}

Each family has an average of five children. Illiterate parents, unsuitable environment, poor background, and lack of interest for school in children are some of the major factors creating child labour and poverty is the seed bed of all. They consider children as a source of earning, so they welcome more and more children to engage in domestic work, collection of wood, tin and plastics, automobile workshops, cycle repairing, shoe shining, and hotel and restaurant works. Girl child labourers are engaged for 10-12 hours in household works with low wages bereft of holidays or any other enjoyment. Thus, a child labourer's life in Cuttack city is characterized by low education, poor living, bad working and living conditions, insecurity of jobs, low income, long hours of work etc. Normally they are from poor and larger families who are forced to join labour force to supplement their family income.

To conclude, children's development and the overall eradication of child labour problem of Cuttack depend on active public private partnership, proper government policies and programmes for eliminating poverty and unemployment, free basic facilities, awareness among the people, active participation of the citizens and local bodies, education to extreme poor and particularly women's education should be encouraged.

[1]. Accelerating Action Against Child Labour 2010-International Labour. www.ilo.org/ipecinfo/product/download.do?type=document\&id.

[2]. Burra, N. (1989). Out of Sight Out of Mind: Working Girls in India. International Labour Review, 128 (5), $651-660$.

[3]. Dixit, A. (1997). Labour Force Participation of Girl Child in India. The Indian Journal of Labour Economics, 40 (4).

[4]. ILO Child Labour Statistics of India. http://www.ilo.org/dyn/clsurvey/lfsurvey.list?p_lang=en\&p_country.

[5]. Kanbargi, R. (1991). Child Labour in Indian Sub-Continent: Dimensions and Implications. New Delhi: Sage Publications.

[6]. Mustafa, M. and Onkar, S. (1990). Child Labour in India: A Biller Truth. Bombay: Asia Publishing House.

[7]. Naidu, M. C. (1985). Focus on Child Labour: The State of the World's Children. New York: Oxford University Press.

[8]. Nangia, P. (1991). Child Labour: Cause-Effect Syndrome. New Delhi: Janak Publisher.

[9]. National Child Labour Project Society, Cuttack, Odisha. http://cuttack.nic.in/education/NCLP/nclp-project-02.01.08.doc.

[10]. New ILO Global Report on Child Labour: As Efforts to End Child Labour. http://www.ilo.org/global/about-theilo/newsroom/news/WCMS_126840/lang en/index.htm.

[11]. NSSO (2009-10). 66th Round of Survey on Child Labour in Major Indian States. http://www.mospi.gov.in.

[12]. Pati, R. N. (1991). Rehabilitation of Child Labour in India. New Delhi: Ashish Publishing House.

[13]. Rena, R. 2007. Child Rights Convention and Its Implementation. Indian Ocean Digest, 22 (1\&2), 1-11

[14]. Report on Child Labour. Census of India. (1991 \& 2001). http://censusindia.gov.in.

[15]. State Labour Institute. (2011-12). Child Labour (6-14) Survey in NCLP Districts of Odisha, Labour \& Employment Department, Odisha, Bhubaneswar.

[16]. Subramanian, M. S. (1990). Work Force Participation of Child Labour in the Rural Economy of India. Indian Journal of Labour Economics, 33 (4), Oct-Dec.

[17]. Tripathy, S. K. (1989). Child Labour in India. New Delhi: Discovery Publishing House.

[18]. Tripathy, S. N. (1991). Child Labour: A Study in Bhubaneswar. The Indian Journal of Labour Economics, 40 (4).

[19]. UNICEF Child Labour Statistics of India.

http://www.unicef.org/infobycountry/india_statistics.html. 